\title{
Nitrogen and carbon isotopic composition of high-molecular-weight dissolved organic matter in marine environments
}

\author{
Laodong Guo ${ }^{1, *}$, Noriyuki Tanaka ${ }^{1}$, Donald M. Schell ${ }^{2}$, Peter H. Santschi ${ }^{3}$ \\ ${ }^{1}$ International Arctic Research Center, and ${ }^{2}$ Institute of Marine Science, University of Alaska Fairbanks, Alaska 99775, USA \\ ${ }^{3}$ Department of Oceanography, Texas A\&M University, Galveston, Texas 77551, USA
}

\begin{abstract}
High-molecular-weight (HMW) dissolved organic matter (DOM) was isolated using cross-flow ultrafiltration from seawater across a salinity gradient in 2 estuarine/coastal marine environments-Chesapeake Bay/Middle Atlantic Bight (MAB) and Galveston Bay/Gulf of Mexico. Nitrogen and carbon isotope ratios $\left(\delta^{15} \mathrm{~N}\right.$ and $\left.\delta^{13} \mathrm{C}\right)$ were measured on the isolated HMW DOM samples (defined here as the size fraction between 1 and $200 \mathrm{~nm}$ ), which made up 50 to $60 \%$ of the total DOM in the estuarine regions and decreased to $\sim 35 \%$ of the DOM at the MAB and Gulf of Mexico stations. $\delta^{15} \mathrm{~N}$ values varied from 4.8 to $8.1 \%$ in the Chesapeake Bay/MAB area. In the Galveston Bay/Gulf of Mexico region, $\delta^{15} \mathrm{~N}$ and $\delta^{13} \mathrm{C}$ values varied from 3.2 to $9.5 \%$ and -26.1 to $-20.9 \%$, respectively. Similar distribution patterns of $\delta^{13} \mathrm{C}$ and $\delta^{15} \mathrm{~N}$ were observed in both study areas, with values of $\delta^{15} \mathrm{~N}$ showing a mid-salinity maximum of about 8 to $10 \%$, whereas $\delta^{13} \mathrm{C}$ continually increased with increasing salinity. The $\delta^{13} \mathrm{C}$ values clearly demonstrated a shift of HMW organic carbon sources from largely terrestrial inputs in the upper-estuarine areas to marine-dominated organic carbon sources in lower-estuarine and coastal regions. The more complicated distribution patterns of $\delta^{15} \mathrm{~N}$, with $\delta^{15} \mathrm{~N}$ values first increasing with salinity in estuarine regions then decreasing towards the seawater endmember, suggest more dynamic N cycling. Thus, in addition to organic matter sources, biogeochemical and isotopic fractionation processes are important factors governing marine HMW DOM $\delta^{15} \mathrm{~N}$ values. Vertical profiles of HMW DOM $\delta^{13} \mathrm{C}$ in open-ocean stations generally decrease from surface water to deep waters, whereas the opposite was found for $\delta^{15} \mathrm{~N}$. HMW DOM components with heavier $\delta^{13} \mathrm{C}$ and lighter $\delta^{15} \mathrm{~N}$ values seem to be preferentially degraded during their transport from surface to deep waters. However, other processes could also have contributed to this distribution trend. While the carbon isotopic signature can be used as an indicator of DOM sources, nitrogen isotopic composition, on the other hand, appears to be related to both source functions and subsequent recycling in marine environments. Comparisons of $\delta^{15} \mathrm{~N}$ with previously published $\Delta^{14} \mathrm{C}$ values for the same samples support these conclusions about possible ${ }^{15} \mathrm{~N}$ degradation pathways.
\end{abstract}

KEY WORDS: Dissolved organic matter $\cdot$ Stable isotopes $\cdot$ Colloids $\cdot$ Estuary $\cdot$ Ultrafiltration $\cdot$ Seawater

\section{INTRODUCTION}

Dissolved organic matter (DOM) in seawater is one of the major components in the global carbon cycle, but its cycling rates and biogeochemical behavior in the ocean remain largely unknown (Hedges 1992, Lee \& Wakeham 1992). Understanding the biogeochemical cycling of marine DOM has been hampered by its poor chemical and isotopic characterization. The applica- tion of ultrafiltration techniques to marine systems has allowed the concentration and isolation of highmolecular-weight (HMW) DOM for chemical and isotopic analysis (Benner et al. 1992a, Guo et al. 1995), which has improved our understanding of the origin, reactivity and fate of DOM in marine environments (e.g. Benner et al. 1992a, Hedges et al. 1994, Santschi et al. 1995, Guo et al. 1996, Aluwihare et al. 1997, McCarthy et al. 1997, Clark et al. 1999, Mannino 
\& Harvey 2000). There is convincing evidence that organic carbon flows are largely from particulate organic matter (POM) to HMW DOM to low-molecularweight (LMW) DOM (Santschi et al. 1995, Guo et al. 1996, Guo \& Santschi 1997b), with the HMW DOM being an important intermediary component between easily degradable POM and LMW DOM. However, the isotopic and molecular composition of HMW DOM remain poorly characterized.

Nitrogen and carbon isotopic signatures have been proven to be useful tracers of sources, sinks and transformations of marine organic matter, as well as nutrients (Sackett 1989, Rau et al. 1990, 1991, Druffel \& Williams 1992, Altabet \& Francois 1994). However, while the application of isotopic techniques to plankton, POM and sedimentary organic matter has been widely reported (e.g. Altabet et al. 1991, Rau et al. 1991, Schell et al. 1998, Sachs et al. 1999, Struck et al. 2001), measurements of nitrogen and carbon isotopes for marine DOM are still limited, especially for HMW DOM samples (Guo \& Santschi 1997a, and references therein). Data on nitrogen isotopic natural abundances for DOM are even scarcer in the literature.

Sigleo \& Macko (1985) first measured $\delta^{15} \mathrm{~N}$ and $\delta^{13} \mathrm{C}$ values on estuarine organic matter in the $5 \mathrm{kDa}$ to $0.4 \mu \mathrm{m}$ size-fraction, with a $\delta^{13} \mathrm{C}$ value of $-24.8 \%$ and $\delta^{15} \mathrm{~N}$ values ranging from 8.5 to $10.8 \%$. Benner et al. (1992b) reported $\delta^{13} \mathrm{C}$ and $\delta^{15} \mathrm{~N}$ values of HMW (1 kDa to $0.2 \mu \mathrm{m}) \mathrm{DOM}$ in the Mississippi River plume. Benner et al. (1997) further reported an extensive data set of $\delta^{13} \mathrm{C}$ and $\delta^{15} \mathrm{~N}$ values of marine HMW DOM (1 kDa to $0.1 \mu \mathrm{m}$ or 1 to $100 \mathrm{~nm}$ ) samples from the Gulf of Mexico, Pacific and Atlantic Oceans. They found fairly constant $\delta^{13} \mathrm{C}$ values for the HMW DOM samples (with an average of $-21.7 \pm 0.2 \%$ ) but more variable $\delta^{15} \mathrm{~N}$ values, ranging from 6.6 to $10.2 \%$ (Benner et al. 1997).

Previous studies have found that the carbon isotopic ratios of marine POM vary significantly, with nutrient abundance, concentration of $\mathrm{CO}_{2}$ and plankton growth rates being important factors for establishing the isotopic regimes in marine environments (Saino 1992, Schell et al. 1998, and references therein). However, stable carbon isotope ratios of DOM in the ocean are relatively constant with depth and geographic region, with a narrow range between -20 and $-22 \%$ (Williams 1968, Eadie et al. 1978). In addition, changes of $\delta^{13} \mathrm{C}$ resulting from trophic transfers are minimal. In contrast, significant and consistent differences in nitrogen isotopic ratios have been observed for both particulate and colloidal organic matter (e.g. Altabet 1988, Benner et al. 1997), with an increased enrichment in $\delta^{15} \mathrm{~N}$ values (about 3 to $4.5 \%$ ) with each trophic level (Minagawa \& Wada 1984). It is expected that a combination of both carbon and nitrogen isotopic signatures should provide better information about sources and cycling mechanisms and pathways of DOM in estuarine and marine environments than just $\mathrm{C}$ isotopes alone. With the currently limited data sets on both $\delta^{13} \mathrm{C}$ and $\delta^{15} \mathrm{~N}$ results for estuarine and marine DOM, more simultaneous measurements on the same samples are needed. This is especially important for HMW DOM, as it is being considered as a transitory phase between POM and LMW DOM.

In the present study, 2 estuarine and coastal marine environments, i.e. Chesapeake Bay/Middle Atlantic Bight (MAB) and Galveston Bay/Gulf of Mexico regions, were chosen as study areas, each showing dynamic changes in biological properties, water chemistry, and water mixing along freshwater to marine transects in these estuaries. High-molecular-weight (HMW, $1 \mathrm{kDa}$ to $0.2 \mu \mathrm{m}$, or about 1 to $200 \mathrm{~nm}$ ) DOM was quantified for concentration and samples isolated for isotopic analysis across spatial and vertical scales.

\section{MATERIALS AND METHODS}

Study areas. Surface water samples were collected from the Chesapeake Bay to the MAB and from Galveston Bay to the Gulf of Mexico (Table 1). Stations were designed to cover a salinity gradient in the estuarine and coastal regions. In addition, deep stations were sampled to examine vertical variations.

Galveston Bay is one of the largest estuaries on the Gulf of Mexico coast and receives river inputs from the Trinity and the San Jacinto Rivers. The annual freshwater inflow into Galveston Bay is about $1.24 \times 10^{10} \mathrm{~m}^{3}$, with $\sim 83 \%$ of the total freshwater inflow coming from the Trinity River (Orlando et al. 1993). Chesapeake Bay, with most freshwater input from the Susquehanna River, is the largest estuary on the US east coast and contributes a large flux of freshwater and organic matter to the North Atlantic Ocean (Sanford et al. 2001). Detailed sampling locations are listed in Table 1 with water depth, water temperature, and salinity at each station.

Sampling. Surface water $(0.5$ to $1 \mathrm{~m})$ was peristaltically pumped through a pre-rinsed $0.2 \mu \mathrm{m}$ Nuclepore cartridge into either an ultrafiltration reservoir or a 201 plastic container for ultrafiltration. The in-line prefilter system (Nuclepore cartridges and tubing) was cleaned before use by recirculation with $2 \mathrm{~N} \mathrm{HCl}$ solution and subsequently rinsed with large volumes of Nanopure water. Before collecting samples, the first 101 of filtered water were discarded, and the containers were then rinsed with the prefiltered water. At estuarine stations, 40 l of prefiltered water was collected for ultrafiltration. At open Gulf of Mexico and MAB stations, large volumes of prefiltered water (up to 500 l) were used for ultrafiltration (Guo et al. 1996). 
Ultrafiltration. HMW DOM (defined as the fraction between $1 \mathrm{kDa}$ and $0.2 \mu \mathrm{m}$ or about 1 to $200 \mathrm{~nm}$ ) was isolated from prefiltered seawater using cross-flow ultrafiltration (Guo \& Santschi 1996, Guo et al. 2000). Estuarine water $(<0.2 \mu \mathrm{m})$ was ultrafiltered using an Amicon DC10 system equipped with $2 \times 1 \mathrm{kDa}$ ultrafiltration cartridges (Amicon S10N1), while coastal and open seawater was processed on a DC-30 ultrafiltration system equipped with 9 S10N1 ultrafiltration cartridges. Ultrafiltration cartridges were checked for integrity and thoroughly cleaned before sampling using Micro detergent, $\mathrm{NaOH}, \mathrm{HCl}$, and large volumes of Nanopure water (with a DOC concentration of $\sim 2 \mu \mathrm{M})$. Cartridges were also cleaned between each sample collection. Details of the cleaning and calibration procedures are described in Guo \& Santschi (1996) and Guo et al. (2000). No evidence for fractionation effects of major biochemicals of HMW DOM during ultrafiltration was documented (e.g. Guo et al. 2000, 2001 and references therein). The main fractionation effects involve LMW DOM components of MWs close to membranes' cut-offs (Guo et al. 2000, 2001). Such components are efficiently washed out by subsequent diafiltration.

Surface water samples from the Chesapeake Bay, the MAB and the Gulf of Mexico were ultrafiltered on board immediately after collection. Ultrafiltration was carried out within 4 to $8 \mathrm{~h}$ of sample collection for Galveston Bay samples. Isolated HMW DOM concentrates were then desalted by diafiltration using $20 \mathrm{l}$ of Nanopure water, and subsequently freeze dried for isotopic and elemental characterization. Aliquots of filtered and ultrafiltered seawater were also sampled for measurements of concentrations of dissolved (DOC) and colloidal organic carbon (COC) using the hightemperature combustion method (Guo et al. 1995).

Table 1. Surface water sampling locations, water depth, temperature, salinity and concentrations of dissolved (DOC) and colloidal organic carbon $(\mathrm{COC})$, colloidal organic nitrogen $(\mathrm{CON})$, and stable carbon $\left(\delta^{13} \mathrm{C}\right)$ and nitrogen $\left(\delta^{15} \mathrm{~N}\right)$ isotopic composition of high-molecular-weight dissolved organic material (DOM). Concentrations of CON were estimated from measured COC concentrations and the C:N ratio of the corresponding dried colloidal organic matter (COM) sample (Guo et al. 1996, Guo \& Santschi 1997b). -: not measured

\begin{tabular}{|c|c|c|c|c|c|c|c|c|c|}
\hline Stn & Location & $\begin{array}{c}\text { Water } \\
\text { depth (m) }\end{array}$ & $\begin{array}{l}\text { Temp } \\
\left({ }^{\circ} \mathrm{C}\right)\end{array}$ & Salinity & $\begin{array}{l}\text { DOC } \\
(\mu \mathrm{M})\end{array}$ & $\begin{array}{l}\text { COC } \\
(\mu \mathrm{M})\end{array}$ & $\begin{array}{l}\text { CON } \\
(\mu \mathrm{M})\end{array}$ & $\begin{array}{l}\delta^{13} \mathrm{C} \\
(\%)\end{array}$ & $\begin{array}{l}\delta^{15} \mathrm{~N} \\
(\% \circ)\end{array}$ \\
\hline \multicolumn{10}{|c|}{ Chesapeake Bay (CB) and Middle Atlantic Bight (MAB) } \\
\hline CB/MAB-02 & $76^{\circ} 20^{\prime} \mathrm{W}, 39^{\circ} 06^{\prime} \mathrm{N}$ & 6.5 & 27.5 & 5.0 & 193 & 125 & 5.8 & - & 6.10 \\
\hline CB/MAB-04 & $76^{\circ} 25^{\prime} \mathrm{W}, 39^{\circ} 05^{\prime} \mathrm{N}$ & 30 & 27.0 & 9.1 & 205 & 133 & 6.1 & - & 7.59 \\
\hline CB/MAB-05 & $76^{\circ} 20^{\prime} \mathrm{W}, 38^{\circ} 22^{\prime} \mathrm{N}$ & 21 & 26.9 & 10.4 & 211 & 129 & 6.3 & - & 6.47 \\
\hline CB/MAB-06 & $76^{\circ} 10^{\prime} \mathrm{W}, 37^{\circ} 55^{\prime} \mathrm{N}$ & 18 & 26.0 & 15.0 & 215 & 112 & 5.8 & - & 7.23 \\
\hline $\mathrm{CB} / \mathrm{MAB}-07$ & $76^{\circ} 05^{\prime} \mathrm{W}, 37^{\circ} 24^{\prime} \mathrm{N}$ & 15 & 25.5 & 18.2 & 122 & 76 & 3.7 & - & 8.11 \\
\hline CB/MAB-08 & $76^{\circ} 05^{\prime} \mathrm{W}, 36^{\circ} 55^{\prime} \mathrm{N}$ & 20 & 25.0 & 25.0 & 118 & 67 & 3.4 & - & 6.81 \\
\hline CB/MAB-09 & $75^{\circ} 14^{\prime} \mathrm{W}, 36^{\circ} 30^{\prime} \mathrm{N}$ & 25 & 23.6 & 35.2 & 119 & 63 & 3.1 & - & 7.34 \\
\hline $\mathrm{CB} / \mathrm{MAB}-10$ & $75^{\circ} 10^{\prime} \mathrm{W}, 36^{\circ} 06^{\prime} \mathrm{N}$ & 30 & 22.9 & 35.59 & 98 & 33 & 2.6 & - & 6.61 \\
\hline CB/MAB-11 & $74^{\circ} 50^{\prime} \mathrm{W}, 36^{\circ} 06^{\prime} \mathrm{N}$ & 100 & 26.5 & 36.27 & 88 & 37 & 2.3 & - & 4.85 \\
\hline CB/MAB-12 & $74^{\circ} 14^{\prime} \mathrm{W}, 36^{\circ} 00^{\prime} \mathrm{N}$ & 2350 & 25.3 & 36.08 & 85 & 29 & 2.4 & - & 5.31 \\
\hline CB/MAB-13 & $74^{\circ} 04^{\prime} \mathrm{W}, 36^{\circ} 09^{\prime} \mathrm{N}$ & 2650 & 27.2 & 36.01 & 82 & 28 & 2.6 & - & 5.18 \\
\hline \multicolumn{10}{|c|}{ Galveston Bay (GB) and Gulf of Mexico (GOM) } \\
\hline GB/GOM-TR & Trinity River & 2 & - & 0 & 417 & 275 & 11.5 & - & 6.83 \\
\hline GB/GOM-02 & - & 2.1 & - & 0.2 & 435 & 270 & 11.3 & -25.89 & 6.52 \\
\hline GB/GOM-03 ${ }^{\mathrm{a}}$ & - & - & - & 2.3 & 434 & - & - & -25.89 & 7.35 \\
\hline GB/GOM- $04^{\mathrm{a}}$ & - & - & - & 5 & 446 & 276 & 12.6 & -25.71 & 7.41 \\
\hline GB/GOM-0 $05^{\mathrm{a}}$ & - & - & - & 7 & 436 & - & - & -25.90 & 7.98 \\
\hline GB/GOM-06 $6^{\mathrm{a}}$ & - & - & - & 10 & 416 & 258 & 12.0 & -25.81 & 8.19 \\
\hline GB/GOM- $07^{\mathrm{a}}$ & - & - & - & 12 & 417 & 259 & 12.6 & -26.09 & 8.88 \\
\hline GB/GOM-08 ${ }^{\mathrm{a}}$ & - & - & - & 15 & 366 & - & - & -25.64 & 9.22 \\
\hline GB/GOM-09a & - & - & - & 17 & 326 & 195 & 10.2 & -25.19 & 8.20 \\
\hline GB/GOM-10 & - & - & - & 20 & 308 & - & - & -25.22 & 9.50 \\
\hline GB/GOM-11 ${ }^{\mathrm{a}}$ & - & - & - & 22 & 264 & 156 & 8.5 & -24.56 & 8.95 \\
\hline GB/GOM-12 $2^{\mathrm{a}}$ & - & - & - & 25 & 205 & - & - & -24.62 & 8.18 \\
\hline GB/GOM-13 & - & 4 & - & 29.8 & 201 & 111 & 6.2 & -24.01 & 9.23 \\
\hline GB/GOM-14 & - & 8 & - & 33.9 & 160 & 82 & 4.5 & -23.31 & 6.25 \\
\hline GB/GOM-15 & $94^{\circ} 44^{\prime} \mathrm{W}, 28^{\circ} 45^{\prime} \mathrm{N}$ & 18 & 19.0 & 35.032 & 86 & 36 & 2.1 & -21.36 & 4.22 \\
\hline GB/GOM-16 & $94^{\circ} 43^{\prime} \mathrm{W}, 28^{\circ} 44^{\prime} \mathrm{N}$ & 105 & 22.4 & 35.679 & 84 & 31 & 1.9 & -22.69 & 3.20 \\
\hline GB/GOM-17 & $95^{\circ} 50^{\prime} \mathrm{W}, 27^{\circ} 30^{\prime} \mathrm{N}$ & 380 & 23.4 & 35.908 & 82 & 29 & 1.8 & -21.73 & 4.59 \\
\hline GB/GOM-18 & $95^{\circ} 00^{\prime} \mathrm{W}, 26^{\circ} 40^{\prime} \mathrm{N}$ & 1650 & 23.8 & 36.406 & 70 & 28 & 1.6 & -20.91 & 3.46 \\
\hline
\end{tabular}


Measurements of organic $C, N, \delta^{13} C$ and $\delta^{15} N$. The isolated HMW DOM samples were measured for their $\mathrm{C}$ and $\mathrm{N}$ concentrations and isotopic composition $\left({ }^{13} \mathrm{C}\right.$ and $\left.{ }^{15} \mathrm{~N}\right)$. Stable carbon and nitrogen isotope ratios were calculated in terms of $\delta^{13} \mathrm{C}$ and $\delta^{15} \mathrm{~N}$, $\left(R_{\text {sample }} /\right.$ $\left.R_{\text {standard }}-1\right) \times 1000$, where $R$ is the ratio of ${ }^{13} \mathrm{C}:{ }^{12} \mathrm{C}$, or ${ }^{15} \mathrm{~N}:{ }^{14} \mathrm{~N}$, in HMW DOM samples or standards (PDB for carbon and atmospheric $\mathrm{N}_{2}$ for nitrogen). Both $\delta^{13} \mathrm{C}$ and $\delta^{15} \mathrm{~N}$ were measured by continuous-flow isotoperatio mass spectrometry (Schell et al. 1998). The precision and accuracy of $\delta^{13} \mathrm{C}$ and $\delta^{15} \mathrm{~N}$ analysis were \pm 0.1 and $\pm 0.2 \%$, respectively, as determined by replicate analysis of standards and samples.

\section{RESULTS AND DISCUSSION}

\section{Concentrations of HMW DOM}

Concentrations of DOC in surface seawaters ranged from 118 to $215 \mu \mathrm{M}$ at Chesapeake Bay stations and from 82 to $98 \mu \mathrm{M}$ at MAB stations (Table 1). Galveston Bay waters had higher DOC concentrations that varied from 160 to $446 \mu \mathrm{M}$ during the sampling period while they were lower in Gulf of Mexico surface waters, ranging from 70 to $86 \mu \mathrm{M}$ (Table 1). For the 1 to $200 \mathrm{~nm}$ colloidal fraction in surface waters, COC made up $\sim 59 \%$ of the DOC in Chesapeake Bay, and decreased to $\sim 35 \%$ of DOC in MAB. Similarly, COC was about $60 \%$ of the DOC in Galveston Bay and decreased to $35-42 \%$ of the DOC in Gulf of Mexico (Table 1).

While concentrations of COC were directly measured by TOC analysis, those of colloidal organic nitrogen (CON) were determined indirectly. Using the C:N ratio of freeze-dried colloidal organic matter (COM) samples and our measured COC concentrations, CON concentrations were then calculated and listed in Table 1. As shown in Table 1, CON concentrations were 2.3 to $6.3 \mu \mathrm{M}$ in the Chesapeake Bay/MAB area, while they were 1.6 to $12 \mu \mathrm{M}$ in the Galveston Bay/
Gulf of Mexico region. Overall, concentrations of both $\mathrm{COC}$ and CON were relatively higher in Galveston Bay/Gulf of Mexico compared to those in the Chesapeake Bay/MAB area, but reached similar values in the surface waters of open Gulf and MAB regions (Table 1). The detailed distribution and dynamic features of DOC and COC in the study areas are presented elsewhere (Guo et al. 1995, Guo \& Santschi 1997b).

\section{${ }^{15} \mathrm{~N}$ and ${ }^{13} \mathrm{C}$ natural abundance in DOM}

Values of nitrogen and carbon isotopic ratios $\left(\delta^{15} \mathrm{~N}\right.$ and $\delta^{13} \mathrm{C}$ ) of HMW DOM samples are listed in Table 1 for the Chesapeake Bay/MAB and Galveston Bay/Gulf of Mexico regions and compared with literature data in Table 2. $\delta^{15} \mathrm{~N}$ values in the Chesapeake Bay/MAB region varied from 4.8 to $8.1 \%$, with the highest values determined in the mid-estuarine region and the lowest values at the coastal and open-ocean stations (Table 1). In the Galveston Bay/Gulf of Mexico area, values of $\delta^{15} \mathrm{~N}$ in the HMW DOM changed from $3.2 \%$ at the open-gulf stations to $9.5 \%$ in the mid-estuarine regions. These $\delta^{15} \mathrm{~N}$ values are similar to those measured for the Chesapeake Bay/MAB samples, but exhibited a greater range (Table 1). Values of $\delta^{13} \mathrm{C}$ in the Galveston Bay/Gulf of Mexico region ranged from -26.1 to $-20.9 \%$, with a general trend of $\delta^{13} \mathrm{C}$ value increasing from estuarine to coastal waters.

$\delta^{13} \mathrm{C}$ and $\delta^{15} \mathrm{~N}$ measurements on freshwater and marine DOM from the available literature are compiled in Table 2. In general, our measured HMW DOM $\delta^{13} \mathrm{C}$ and $\delta^{15} \mathrm{~N}$ values are within the ranges previously reported. Values of $\delta^{15} \mathrm{~N}$ from lake water reported by Feuerstein et al. (1997) appear to be low compared to other available marine DOM data listed in Table 2. The reason for this difference between freshwater and seawater is not clear. The reported marine DOM $\delta^{15} \mathrm{~N}$ values ( 3 to $10.8 \%$ ) are generally higher than those

Table 2. Comparison of isotopic abundance $\left(\delta^{13} \mathrm{C}\right.$ and $\left.\delta^{15} \mathrm{~N}\right)$ in natural dissolved organic matter (DOM)

\begin{tabular}{|lcccl|}
\hline Location & DOM fraction & $\delta^{13} \mathrm{C}(\%)$ & $\delta^{15} \mathrm{~N}(\%)$ & Source \\
\hline Patuxen estuary & $5 \mathrm{kDa}-0.4 \mu \mathrm{m}$ & -24.8 & 8.5 to 10.8 & Sigleo \& Macko (1985) \\
Mississippi River plume & $1 \mathrm{kDa}-0.2 \mu \mathrm{m}$ & -25 to -21.3 & 3 to 9 & Benner et al. (1992b) \\
Lake Michigan & $0.1 \mathrm{kDa}-0.2 \mu \mathrm{m}$ & - & 2.6 to 5.0 & Feuerstein et al. (1997) \\
Lake Superior & $0.1 \mathrm{kDa}-0.2 \mu \mathrm{m}$ & $-24.6 \pm 0.1$ & $-1.2 \pm 0.3$ & Feuerstein et al. (1997) \\
Pacific Ocean & $1 \mathrm{kDa}-0.2 \mu \mathrm{m}$ & -21.9 to -21.3 & 6.7 to 9.7 & Benner et al. (1997) \\
Atlantic Ocean & $1 \mathrm{kDa}-0.2 \mu \mathrm{m}$ & -22.2 to -21.7 & 6.6 to 8.9 & Benner et al. (1997) \\
Gulf of Mexico & $1 \mathrm{kDa}-0.2 \mu \mathrm{m}$ & -21.3 & 9.5 to 10.2 & Benner et al. (1997) \\
Pacific Ocean & $>0.1 \mathrm{kDa}$ & - & 4 to 14 & Gedeon et al. (2001) \\
Chesapeake Bay/Midle Atlantic Bight & $1 \mathrm{kDa}-0.2 \mu \mathrm{m}$ & -26.5 to -21 & 4.8 to 8.1 & This study \\
Galveston Bay/Gulf of Mexico & $1 \mathrm{kDa}-0.2 \mu \mathrm{m}$ & -26.1 to -21 & 3.2 to 9.2 & This study \\
\hline
\end{tabular}


reported for POM in the upper water column, but close to those in the deeper water column (Altabet 1988). Therefore, higher $\delta^{15} \mathrm{~N}$ values are perhaps related to more diagenetically altered organic components in the marine DOM pool (see discussion in next section).
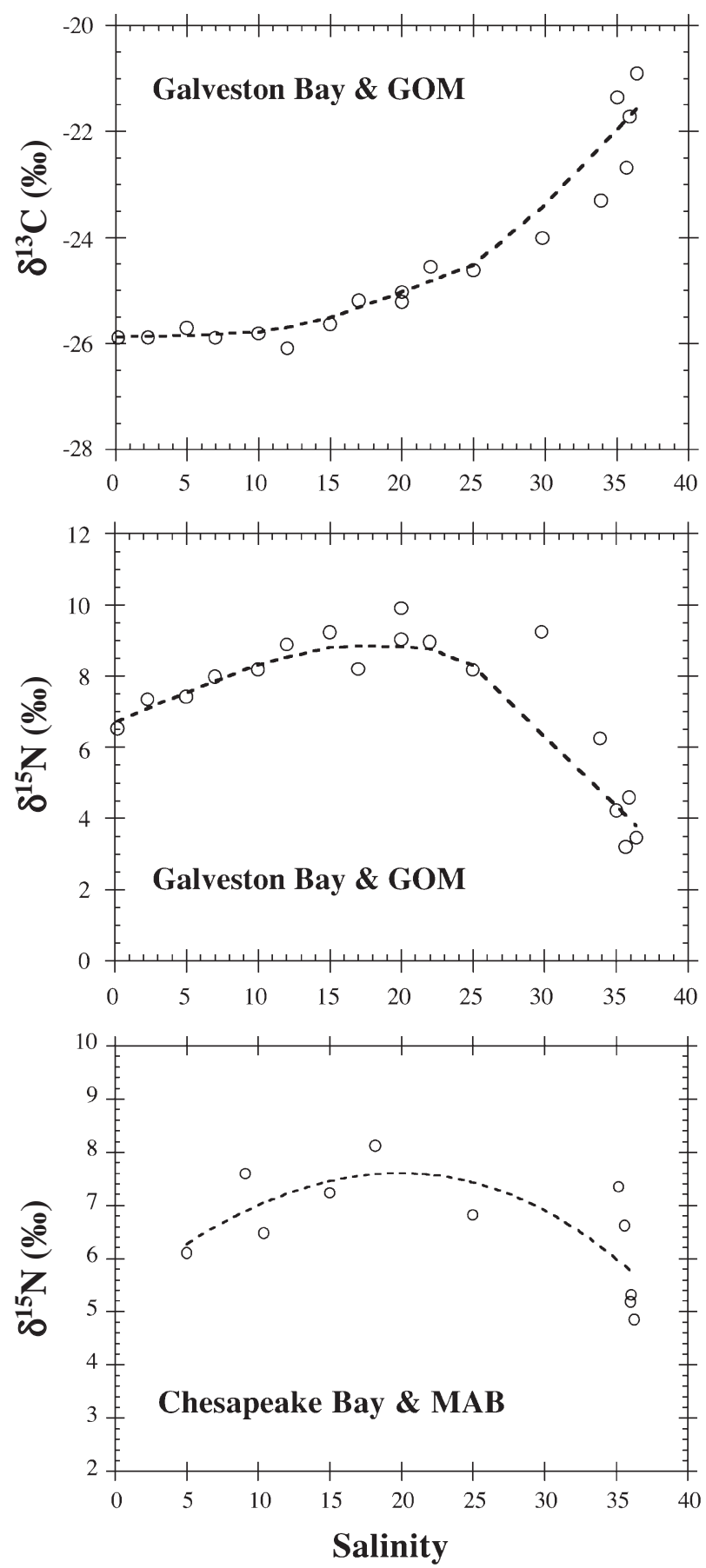

Fig. 1. Variations of $\delta^{13} \mathrm{C}$ and $\delta^{15} \mathrm{~N}$ values in high-molecularweight (HMW) dissolved organic matter (DOM) with salinity in the Galveston Bay/Gulf of Mexico (GOM) and the Chesapeake Bay/Middle Atlantic Bight (MAB) $\left(\delta^{15} \mathrm{~N}\right.$ only) regions

\section{Spatial distributions of $\delta^{13} \mathrm{C}$ and $\delta^{15} \mathrm{~N}$}

Fig. 1 shows the distributions of $\delta^{13} \mathrm{C}$ and $\delta^{15} \mathrm{~N}$ in the HMW DOM in surface waters from the Chesapeake Bay/MAB ( $\delta^{15} \mathrm{~N}$ only) and the Galveston Bay/Gulf of Mexico regions. Values of $\delta^{13} \mathrm{C}$ in the Galveston Bay area increased consistently with increasing salinity (Fig. 1). Lower $\mathrm{C}$ isotopic ratios in the upper-estuarine region are consistent with a terrestrial organic carbon origin. As salinity increased during estuarine mixing, organic carbon sources changed from terrestrially dominated, in the upper-estuarine area, to marinedominated organic carbon in the lower-estuarine regions and open coastal waters.

While the distribution patterns of $\delta^{13} \mathrm{C}$ are consistent with mixing of terrestrial and marine organic matter, $\delta^{15} \mathrm{~N}$ shows a peculiar convex distribution pattern in both study areas (Fig. 1). Values of $\delta^{15} \mathrm{~N}$ first increased with increasing salinity during the early mixing stage in both estuaries (within a salinity $\sim 20$ ) and reached the highest values in the mid-estuary region (salinity 20) and then decreased with increasing salinity in the lower-estuarine region and coastal waters. A similar convex distribution pattern of $\delta^{15} \mathrm{~N}$ in the HMW DOM was also reported for the Mississippi River plume (Benner et al. 1992b). The convex distribution pattern of $\delta^{15} \mathrm{~N}$ implies that values of $\delta^{15} \mathrm{~N}$ are not simply a mixing of distinct DOM sources. Instead, microbial processes (and, possibly, physical sediment resuspension) are leading to isotopic fractionation during transport and degradation of HMW DOM. This may be related to the more complex biogeochemical cycling of nitrogen in seawater (e.g. Bushaw et al. 1996, Bronk \& Ward 1999).

As shown in Fig. 1, changes of $\delta^{15} \mathrm{~N}$ values are relatively small within the estuary (before it reaches the lower-estuarine region). Within the estuarine headwaters, the patterns of $\delta^{15} \mathrm{~N}$ change are similar to the trends of $\delta^{13} \mathrm{C}$. This suggests that the $\mathrm{N}$ isotopic composition of the HMW DOM within the upper- and midestuarine regions is indeed the mixing of terrestrial and marine DOM components. Higher $\delta^{15} \mathrm{~N}$ values in the middle estuary are likely an indicator for diagenetically altered and older DOM components (see discussion below). However, while values of $\delta^{13} \mathrm{C}$ remain high in progressing from estuarine to coastal seawaters, the $\delta^{15} \mathrm{~N}$ values of the HMW DOM decreased from the maximal values ( 8 to $10 \%$ ) in the middle estuary to a value of 3 to $5 \%$ in the open waters. Interestingly, both $\delta^{15} \mathrm{~N}$ and $\delta^{13} \mathrm{C}$ values changed rapidly from the lower estuary towards open coastal waters, although in different directions (Fig. 1). These rapid changes of $\delta^{15} \mathrm{~N}$ and $\delta^{13} \mathrm{C}$ are consistent with the radiocarbon signatures from subsamples of the same materials, which varied from mostly contemporary in the estuary to a 
$\Delta^{14} \mathrm{C}$ value of about -150 to $-200 \%$ in surface water at coastal stations (Guo et al. 1996, Guo \& Santschi 1997b). It seems that HMW DOM deriving from mostly planktonic sources has higher $\delta^{13} \mathrm{C}$ but lower $\delta^{15} \mathrm{~N}$ values.
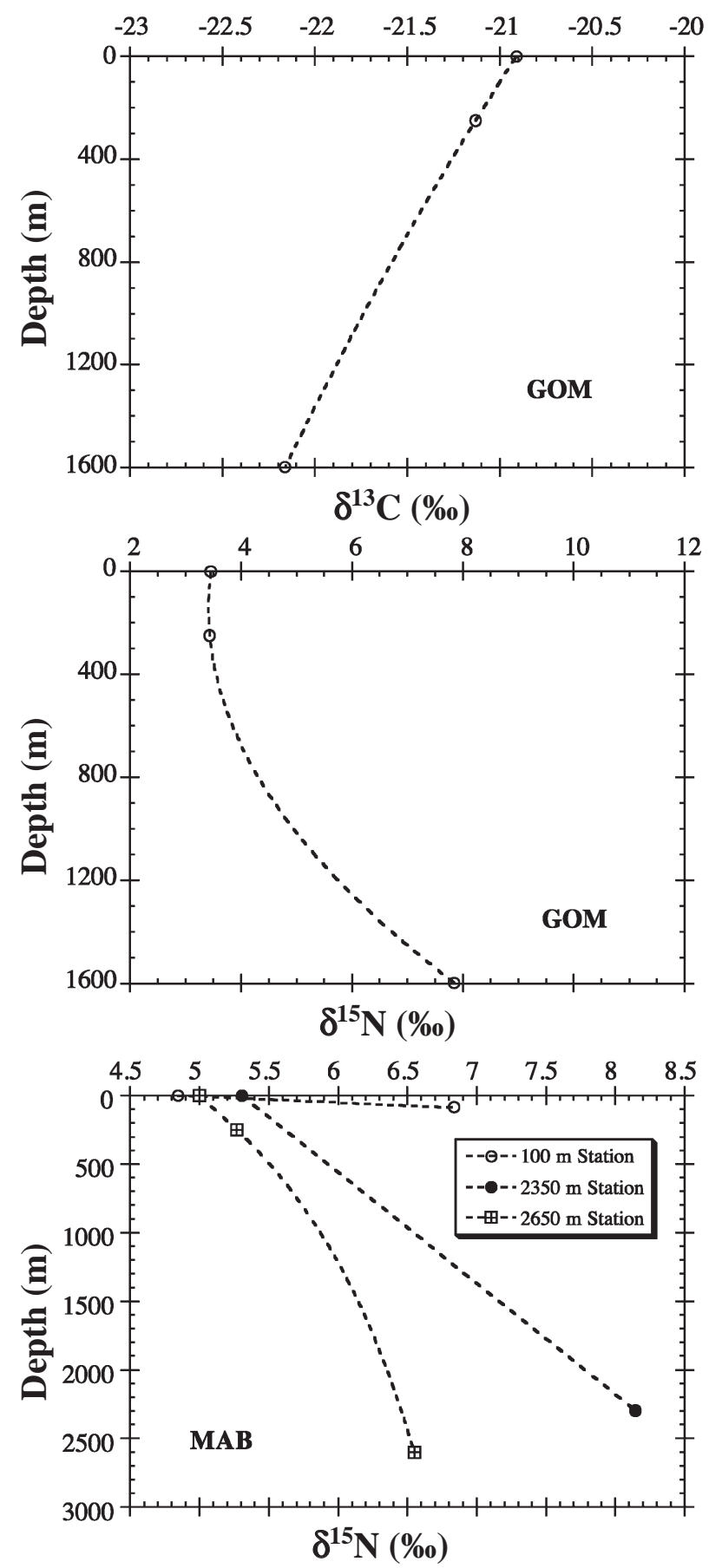

Fig. 2. Vertical profiles of $\delta^{13} \mathrm{C}$ and $\delta^{15} \mathrm{~N}$ values of highmolecular-weight (HMW) dissolved organic matter (DOM) in the water column at stations of the Gulf of Mexico (GOM) and the Middle Atlantic Bight (MAB) $\left(\delta^{15} \mathrm{~N}\right.$ only)

\section{Vertical distribution of $\delta^{15} \mathrm{~N}$ and $\delta^{13} \mathrm{C}$}

Variations of $\delta^{13} \mathrm{C}$ and $\delta^{15} \mathrm{~N}$ values of HMW DOM with water depths at MAB $\left(\delta^{15} \mathrm{~N}\right.$ only) and Gulf of Mexico stations are depicted in Fig. 2. As is evident from these vertical profiles, values of $\delta^{13} \mathrm{C}$ in the HMW DOM samples decreased with increasing water depths in the Gulf of Mexico. If sources of organic matter for the HMW DOM are unique and mostly from the upper water column, the decreasing $\delta^{13} \mathrm{C}$ values with increasing depth could imply that DOM components with heavier carbon isotopic signatures are preferentially degraded during their transport from surface water to deep waters. It is also possible that lateral transport of terrestrial organic components with lighter carbon isotopic signatures may have contributed to the lighter DOM components in deeper waters. This situation is highly likely in ocean-margin regions, especially in the benthic nepheloid layer where sediment resuspension and lateral transport is intensified (Santschi et al. 1999, Guo \& Santschi 2000). However, without direct assessment, this effect cannot be determined with any confidence. It is unknown if this pattern is typical or results from the particular temporal pattern during the sampling period. Similar vertical profiles of $\delta^{13} \mathrm{C}$ were reported for the $>0.1 \mu \mathrm{m}$ POM samples but not the $>1 \mathrm{kDa}$ DOM fraction in the Pacific Ocean (Benner et al. 1997). They found a very narrow range of $\delta^{13} \mathrm{C}$ values for HMW DOM samples with depth.

In contrast to $\delta^{13} \mathrm{C}$, values of $\delta^{15} \mathrm{~N}$ of HMW DOM increased with water depth in both the MAB and the Gulf of Mexico (Fig. 2). Increased $\delta^{15} \mathrm{~N}$ values with increasing water depth point to a preferential loss of lighter nitrogen isotopic organic components during its transport from surface to deep waters. This $\mathrm{N}$ isotopic enrichment pathway is consistent with that derived for POM in previous studies (e.g. Altabet 1988, Thornton \& McManus 1994). Higher $\delta^{15} \mathrm{~N}$ values of DOM at depth are probably related to a more highly degraded state and thus to diagenetically altered, older and refractory HMW DOM components. Again, whether a degradation or lateral transport process is mainly responsible for the vertical distribution of $\delta^{15} \mathrm{~N}$ at these stations remains to be determined. However, similar vertical profiles of $\mathrm{N}$ isotopic ratios were observed for POM and sinking particulate matter in open-ocean environments (e.g. Altabet 1988, Rau et al. 1991, Saino 1992, Benner et al. 1997). Benner et al. (1997) also reported that water column POM normally contains more enriched $\delta^{15} \mathrm{~N}$ values than corresponding DOM in the Pacific Ocean. Likely, lighter nitrogen isotopic components are also preferentially released during decomposition, leaving the POM fraction more enriched with $\delta^{15} \mathrm{~N}$. The other possible mechanism for producing lower $\delta^{15} \mathrm{~N}$ values in the surface water DOM is through $\mathrm{N}$-fixation by 
cyanobacteria (e.g. Wada \& Hattori 1976). Overall, the vertical distribution patterns observed for DOM are consistent with those reported previously for particulate $\delta^{15} \mathrm{~N}$ in the ocean (e.g. Saino \& Hattori 1987, Altabet 1988). It appears that similar degradation processes exist for both DON and PON pools in the ocean.

Considering a 2 component (labile vs refractory) DOM system (Carlson \& Ducklow 1995, Benner et al. 1997), and assuming that DOM is from the same source in the upper water column and without the effect of lateral transport, values of $\delta^{15} \mathrm{~N}$ in the degradable (or labile) organic component in the surface water can be estimated as follows:

$$
\left[\delta^{15} \mathrm{~N}\right]_{\mathrm{sw}}=\left[\delta^{15} \mathrm{~N}\right]_{\mathrm{dw}} \times \mathrm{F}_{\mathrm{dw}}+\left[\delta^{15} \mathrm{~N}\right]_{\text {labile }} \times\left(1-\mathrm{F}_{\mathrm{dw}}\right)
$$

where $\left[\delta^{15} \mathrm{~N}\right]_{\mathrm{sw}}$ is the $\delta^{15} \mathrm{~N}$ value of DOM in surface water, $\left[\delta^{15} \mathrm{~N}\right]_{\mathrm{dw}}$ is the $\delta^{15} \mathrm{~N}$ value of deep water DOM. $\mathrm{F}_{\mathrm{dw}}$ is defined as the refractory DOM fraction in surface waters and, as the first approximation, can be estimated from the ratio of deep water DON concentration to surface water DON concentration, estimated from $\mathrm{N}$ concentrations in the HMW DOM. Results of the estimation of the end-member values of $\delta^{15} \mathrm{~N}$ for labile or degradable DOM in surface waters are listed in Table 3. Interestingly, the labile DOM has an estimated $\delta^{15} \mathrm{~N}$ of $-0.9 \%$ at the Gulf of Mexico station, and $3.8 \%$ at the MAB station. These values are similar to those for surface-water POM values reported by Altabet (1988). The lower estimated $\delta^{15} \mathrm{~N}$ value $(-0.9 \%)$ for the labile DOM component at the Gulf of Mexico station indicates a more freshly photosynthesized DOM component, while a higher $\delta^{15} \mathrm{~N}$ value in the surface water at the MAB station points to a somewhat mixed labile DOM source.

\section{Relationships between the $\mathrm{C}: \mathrm{N}$ ratio, $\delta^{15} \mathrm{~N}, \delta^{13} \mathrm{C}$ and $\Delta^{14} \mathrm{C}$}

When DOM $\delta^{15} \mathrm{~N}$ values were plotted against $\mathrm{NO}_{3}$ concentrations, no significant relationship was found (not shown). While this may partly result from the

Table $3 . \delta^{15} \mathrm{~N}$ values of labile dissolved organic matter (DOM) in surface waters estimated from a 2-component model. Subscripts sw and dw denote surface water and deep water, respectively. DON concentrations were estimated from $\mathrm{C}: \mathrm{N}$ ratios measured on freeze-dried colloidal organic matter samples and measured COC concentrations (Guo et al. 1996, Guo \& Santschi 1997b)

\begin{tabular}{|lcccc|}
\hline Location & $\begin{array}{c}{\left[\delta^{15} \mathrm{~N}\right]_{\mathrm{sw}}} \\
(\%)\end{array}$ & $\begin{array}{c}{\left[\delta^{15} \mathrm{~N}\right]_{\mathrm{dw}}} \\
(\% \circ)\end{array}$ & $\begin{array}{c}{[\mathrm{DON}]_{\mathrm{dw}} /} \\
{[\mathrm{DON}]_{\mathrm{sw}}}\end{array}$ & $\begin{array}{c}{\left[\delta^{15} \mathrm{~N}\right]_{\mathrm{sw} \text { labile }}} \\
(\% \circ)\end{array}$ \\
\hline Gulf of Mexico & 3.46 & 7.85 & 0.50 & -0.93 \\
Middle Atlantic Bight & 5.18 & 6.55 & 0.49 & 3.86 \\
\hline
\end{tabular}

uncertainties in the measurements of low $\mathrm{NO}_{3}$ concentrations in surface waters, such a relationship is not necessarily expected when the main organic matter degradation pathways are from PON to DON via HMW DON. Furthermore, $\delta^{13} \mathrm{C}$ values correlated with COC concentrations, while $\delta^{15} \mathrm{~N}$ values were not correlated with CON concentration (Table 1).

A significant correlation exists between the $\mathrm{C}: \mathrm{N}$ ratios and $\delta^{13} \mathrm{C}$ in all samples measured $\left(\mathrm{R}^{2}=0.69\right.$, $p<0.001$, Fig. 3). This positive correlation supports the premise that HMW DOM with lower $\delta^{13} \mathrm{C}$ values is derived from $\mathrm{N}$-depleted (or $\mathrm{C}$-enriched) DOM components and the more enriched $\delta^{13} \mathrm{C}$ DOM is related to a more $\mathrm{N}$-enriched marine component. However, the relationship between the C:N ratio and $\delta^{15} \mathrm{~N}$ values is very weak $\left(R^{2}=0.26, p<0.2\right.$; Fig. 3$)$, with a relatively large spread in the data points like those observed for estuarine POM samples (e.g. Thornton \& McManus 1994). This scattered relationship suggests the recycling of $\mathrm{N}$ is more intense, with additional factors such as estuarine processing (i.e. microbial and UV degradation, and possibly, organic matter fractionation during sediment resuspension) significantly influencing the $\delta^{15} \mathrm{~N}$ values in DOM (Cifuentes et al. 1988, Thornton \& McManus 1994). This also indicates that DOM with a relatively low $\mathrm{C}: \mathrm{N}$ ratio does not necessarily have to have a heavier $\delta^{15} \mathrm{~N}$ signature, such as that resulting from cyanobacterial $\mathrm{N}$ production. Therefore, production and degradation pathways of nitrogen are more complex in estuarine environments, with different nutrient regimes and planktonic communities (Bronk et al. 1994, Libby \& Wheeler 1997) contributing to isotopic fractionation.

A slightly negative relationship between $\delta^{13} \mathrm{C}$ and $\delta^{15} \mathrm{~N}$ exists for all measured HMW DOM samples $\left(\mathrm{R}^{2}=0.51 ; \mathrm{p}<0.05 ;\right.$ Fig. 3$)$, whereas the relationship between $\delta^{13} \mathrm{C}$ and $\delta^{15} \mathrm{~N}$ for POM in estuarine environments is normally scattered or somewhat positive (e.g. Cifuentes et al. 1988, Thornton \& McManus 1994). The overall relationship between $\delta^{13} \mathrm{C}$ and $\delta^{15} \mathrm{~N}$ shown in Fig. 3 could result from a mixture of different source materials, since these 4 data sets were collected from 2 different estuaries and 2 oceanic environments (Table 1). However, the results appear to be consistent with different degradation pathways of $\mathrm{C}$ and $\mathrm{N}$, as discussed in the previous section.

More revealing are $\Delta^{14} \mathrm{C}$ values from the same HMW DOM samples. Using these available radiocarbon data determined previously on the same samples (Guo 1995, Guo et al. 1996, Guo \& Santschi 1997b), a V-type relationship is found between $\delta^{15} \mathrm{~N}$ and $\Delta{ }^{14} \mathrm{C}$ values 
(Fig. 4). However, when the data are plotted separately for surface-water and deep-water samples, a significant correlation between $\delta^{15} \mathrm{~N}$ and $\Delta^{14} \mathrm{C}$ values for both surface-water $(R=0.86 ; p<0.001)$ and deep-water
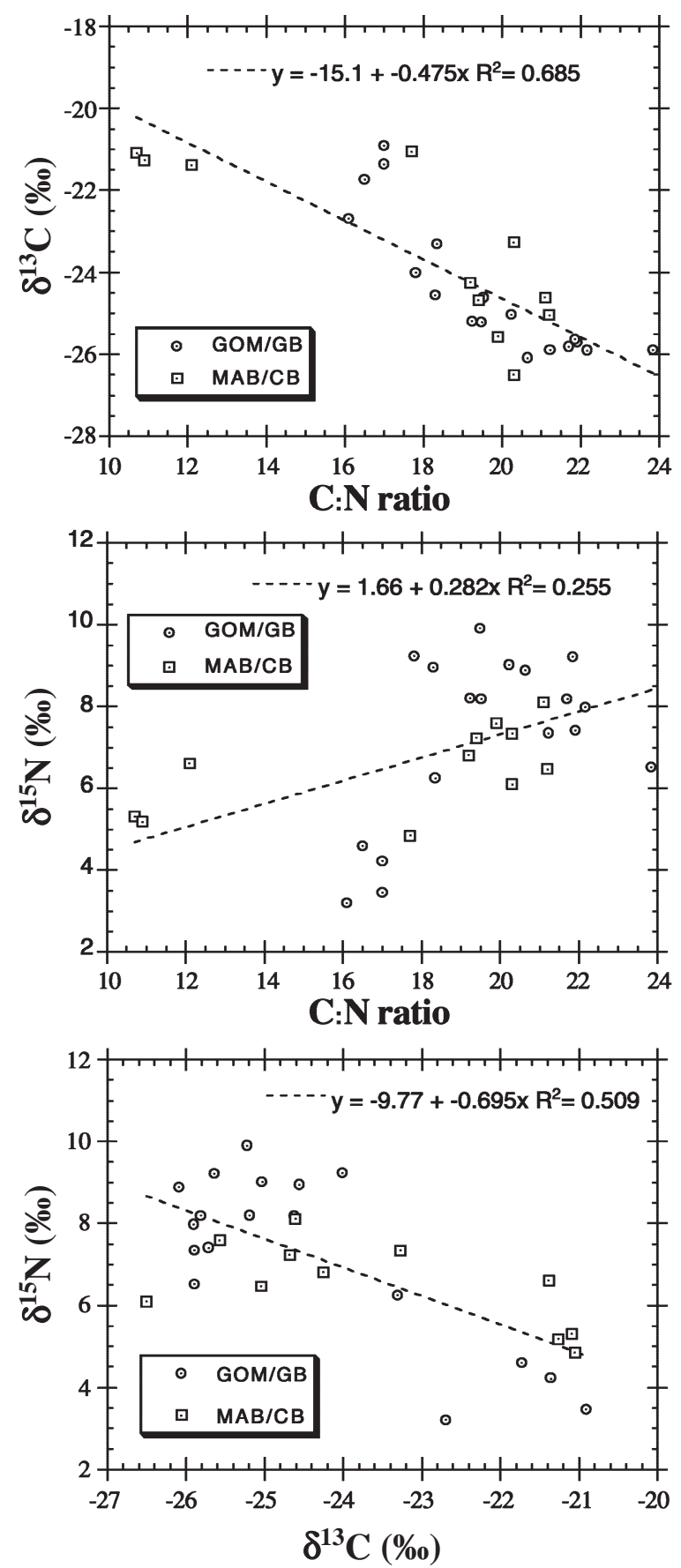

Fig. 3. Relationship between $\mathrm{C}: \mathrm{N}$ ratio, $\delta^{13} \mathrm{C}$ and $\delta^{15} \mathrm{~N}$ in surface water high molecular weight (HMW) dissolved organic matter (DOM) from Gulf of Mexico/Galveston Bay (GOM/GB) and Middle Atlantic Bight/Chesapeake Bay (MAB/CB) regions. $\delta^{13} \mathrm{C}$ data for MAB/CB are from Guo \& Santschi (1997b)
$(\mathrm{R}=0.76 ; \mathrm{p}<0.02)$ samples (see regression lines in Fig. 4) is observed. Values of $\delta^{15} \mathrm{~N}$ are correlated positively with $\Delta^{14} \mathrm{C}$ for surface-water samples (data points between end member A and B in Fig. 4) whereas a negative relationship is found for deep-water samples (data points between end member B and C in Fig. 4). This is the first time that such relationships have been documented for any estuarine and oceanic environments.

Similar relationships between $\delta^{13} \mathrm{C}$ and $\Delta^{14} \mathrm{C}$ were also observed but with opposite correlations (Fig. 4). Values of $\delta^{13} \mathrm{C}$ were negatively correlated with $\Delta^{14} \mathrm{C}$ from end member A to B (Fig. $4, \mathrm{R}=0.78$; $\mathrm{p}<0.01$ ), but positively correlated from end member B to C (Fig. 4 , $\mathrm{R}=0.78 ; \mathrm{p}<0.001)$.
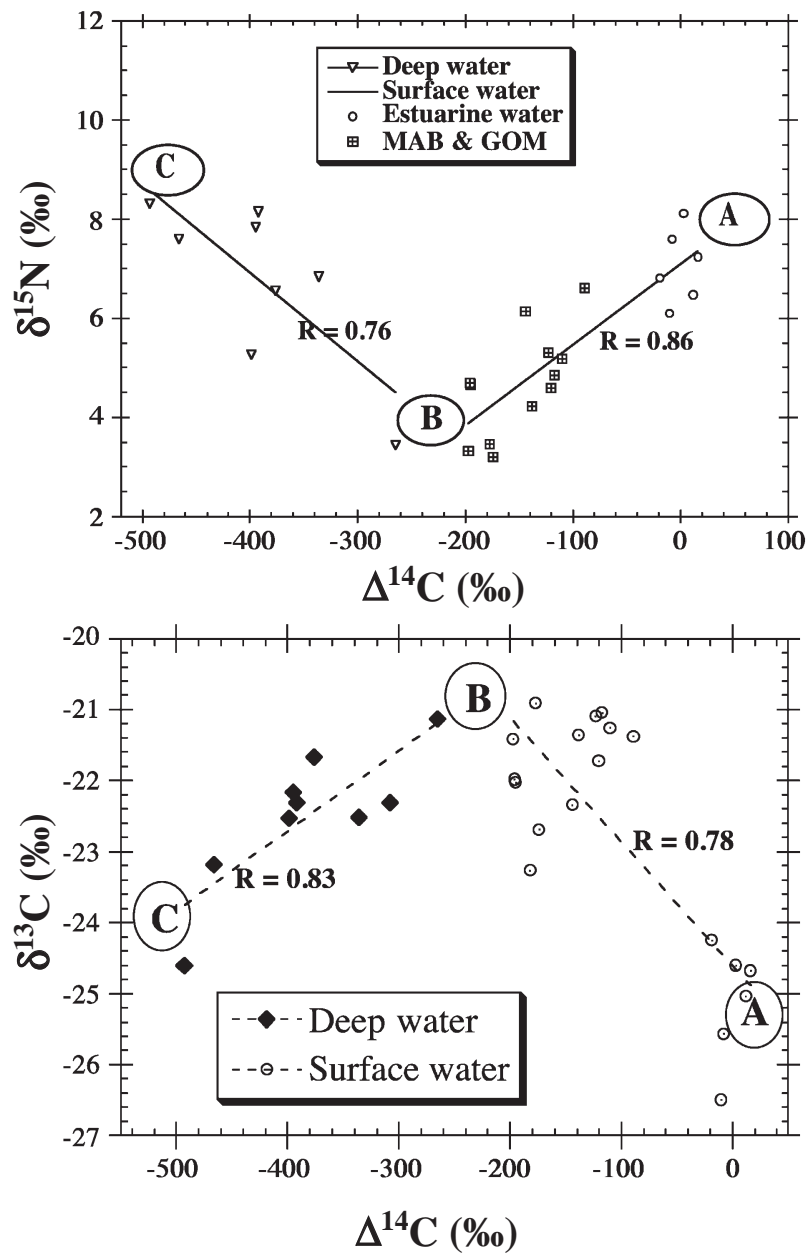

Fig. 4. Relationship between $\delta^{15} \mathrm{~N}$ (or $\delta^{13} \mathrm{C}$ ) and $\Delta^{14} \mathrm{C}$ values in the high-molecular-weight (HMW) dissolved organic matter (DOM) from Chesapeake Bay/ Middle Atlantic Bight (MAB) and the Gulf of Mexico (GOM). Note that 3 end members with distinctive $\delta^{15} \mathrm{~N}$ (or $\delta^{13} \mathrm{C}$ ) and $\Delta^{14} \mathrm{C}$ values, namely estuarine DOM (A), surface oceanic DOM (B) and bottom water DOM (C), respectively, can be easily identified. Radiocarbon data are from Guo (1995), Santschi et al. (1995), Guo et al. (1996) and Guo \& Santschi (1997b) 
From the overall relationship between $\delta^{15} \mathrm{~N}$ (or $\delta^{13} \mathrm{C}$ ) and $\Delta^{14} \mathrm{C}$ (Fig. 4), 3 distinctive end members with different $\mathrm{N}$ isotopic compositions and $\Delta^{14} \mathrm{C}$ values can be identified (labeled as A, B, and C in Fig. 4). In general, surface-water HMW DOM samples with higher $\Delta^{14} \mathrm{C}$ values (or younger ${ }^{14} \mathrm{C}$ ages) possessed higher $\delta^{15} \mathrm{~N}$ (but lower $\delta^{13} \mathrm{C}$ ) values. As values of $\Delta^{14} \mathrm{C}$ decreased, values of DOM $\delta^{15} \mathrm{~N}$ also decreased but $\delta^{13} \mathrm{C}$ increased. For deep-water samples, values of DOM $\delta^{15} \mathrm{~N}$ increased and $\delta^{13} \mathrm{C}$ decreased as $\Delta^{14} \mathrm{C}$ values decreased, in contrast to the surface-water HMW DOM values. This would indicate that, as DOM is transported from surface water to deeper waters, HMW DOM becomes older and older (i.e. lower $\Delta^{14} \mathrm{C}$ values) with $\mathrm{N}$ isotopic ratios getting higher and higher but $\delta^{13} \mathrm{C}$ values getting lower and lower, consistent with the conclusion of preferential decomposition of the lighter $\delta^{15} \mathrm{~N}$ (but heavier $\delta^{13} \mathrm{C}$ ) DOM components derived from vertical profiles shown in Fig. 2.

Nitrogen isotope signatures can thus provide complementary information for the study of the biogeochemistry of marine organic matter. In addition, the combination of multiple isotopic tracers reveals possible mechanisms and pathways of DOM cycling in estuarine and marine environments.

In summary, high-molecular-weight DOM (1 to $200 \mathrm{~nm}$ ) is an important transitory phase between more degradable POM and low-molecular-weight DOM. The overall isotopic fractionation and enrichment processes are distinct for carbon and nitrogen during production, transformation, and degradation pathways of DOM in estuarine and marine environments. Heavier $\delta^{13} \mathrm{C}$ and lighter $\delta^{15} \mathrm{~N}$ DOM components seem to be decomposed preferentially during the transport of organic matter from the upper water column to deep waters, but other possibilities could also have caused these distribution patterns of $\delta^{13} \mathrm{C}$ and $\delta^{15} \mathrm{~N}$ observed here.

Acknowledgements. We thank Kent Warnken, Leah Sauveur, Chris Paternostro, Mark Kershaw, Sarah Oktay, Matt Quigley, Shan Dilards, and crew members of RV 'Gyre' for their assistance during sample collection, Tim Howe and Norma Haubenstock for ${ }^{15} \mathrm{~N}$ and ${ }^{13} \mathrm{C}$ analysis, and 4 anonymous reviewers for valuable comments on the manuscript. This study was supported, in part, by the NSF (OCE-9906823) and the Frontier Research System for Global Change/International Arctic Research Center.

\section{LITERATURE CITED}

Altabet MA (1988) Variations in nitrogen isotopic composition between sinking and suspended particles: implications for nitrogen cycling and particle transformation in the open ocean. Deep-Sea Res 35:535-554

Altabet MA, Francois R (1994) Sedimentary nitrogen isotopic ratio as a recorder for surface ocean nutrient utilization. Global Biogeochem Cycles 8:103-116
Altabet MA, Deuser WG, Honjo S, Stiene C (1991) Seasonal and depth-related changes in the source of sinking particles in the North Atlantic. Nature 354:136-139

Aluwihare LI, Repeta DJ, Chen RF (1997) A major biopolymeric component to dissolved organic carbon in surface seawater. Nature 387:166-169

Benner R, Pakulski JD, McCarthy M, Hedges JI, Hatcher PG (1992a) Bulk chemical characteristics of dissolved organic matter in the ocean. Science 255:1561-1564

Benner R, Chin-Leo C, Gardner W, Eadie B, Cotner J (1992b) The fates and effects of riverine and shelf-derived DOM on Mississippi River plume/Gulf shelf processes. In: Nutrient Enhanced Coastal Ocean Productivity, NECOP Workshop Proceedings, October 1991. TAMU-SG-92-109, NOAA Coastal Ocean Program, Texas SeaGrant, Galveston, TX, p 84-94

Benner R, Biddanda B, Black B, McCarthy M (1997) Abundance, size distribution, and stable carbon and nitrogen isotopic compositions, of marine organic matter isolated by tangential flow ultrafiltration. Mar Chem 57:243-263

Bronk DA, Ward BB (1999) Gross and net nitrogen uptake and DON release in the euphotic zone of Monterery Bay, California. Limnol Oceanogr 44:573-585

Bronk DA, Gilbert PM, Ward BB (1994) Nitrogen uptake, dissolved organic nitrogen release and new production. Science 265:1843-1846

Bushaw KL, Zepp RG, Tarr MA, Schulz-Jander D and 5 others (1996) Photochemical release of biological available nitrogen from aquatic DOM. Nature 381:404-407

Carlson CA, Ducklow HW (1995) Dissolved organic carbon in the upper ocean of the central equatorial Pacific Ocean, 1992: daily and finescale vertical variations. Deep-Sea Res II 42:639-656

Cifuentes L, Sharp JH, Fogel ML (1988) Stable carbon and nitrogen isotope biogeochemistry in the Delaware estuary. Limnol Oceanogr 33:1102-1115

Clark LL, Ingall ED, Benner R (1999) Marine organic phosphorus cycling: novel insights from nuclear magnetic resonance. Am J Sci 2999:724-737

Druffel ERM, Williams PM (1992) Importance of isotope measurements in marine organic geochemistry. Mar Chem 39: 209-216

Eadie BJ, Feffrey LM, Sackett WM (1978) Some observations on the stable carbon isotope composition of dissolved and particulate organic carbon in the marine environment. Geochim Cosmochim Acta 42:1265-1269

Feuerstein TP, Ostrom PH, Ostrom NE (1997) Isotopic biogeochemistry of dissolved organic nitrogen: a new technique and application. Org Geochem 21:363-370

Gedeon ML, Ostrom PH, Ostrom NE, Gandhi H (2001) Simultaneous determination of dissolved organic nitrogen concentrations and isotope values in the subtropical North Pacific. In: ASLO 2001 Aquatic Science Meeting Abstract, February 12-16, 2001, ASLO, Albuquerque

Guo LD (1995) Cycling of dissolved and colloidal organic matter in oceanic environments as revealed by carbon $\left({ }^{13} \mathrm{C}\right.$ and $\left.{ }^{14} \mathrm{C}\right)$ and thorium $\left({ }^{230} \mathrm{Th}\right.$ and $\left.{ }^{234} \mathrm{Th}\right)$ isotopes. $\mathrm{PhD}$ thesis, Texas A\&M University, Galveston

Guo L, Santschi PH (1996) A critical evaluation of cross-flow ultrafiltration technique for sampling colloidal organic carbon in seawater. Mar Chem 55:113-127

Guo L, Santschi PH (1997a) Composition and cycling of colloids in marine environments. Rev Geophys 35:17-40

Guo L, Santschi PH (1997b) Isotopic and elemental characterization of colloidal organic matter from the Chesapeake Bay and Galveston Bay. Mar Chem 59:1-15

Guo L, Santschi PH (2000) Sedimentary source of old high 
molecular weight dissolved organic carbon from the ocean margin benthic nepheloid layer. Geochim Cosmochim Acta 64:651-660

Guo L, Santschi PH, Warnken KW (1995) Dynamics of dissolved organic carbon (DOC) in oceanic environments. Limnol Oceanogr 40:1392-1403

Guo L, Santschi PH, Cifuentes LA, Trumbore S, Southon J (1996) Cycling of high molecular weight dissolved organic matter in the Middle Atlantic Bight as revealed by carbon isotopic $\left({ }^{13} \mathrm{C}\right.$ and $\left.{ }^{14} \mathrm{C}\right)$ signatures. Limnol Oceanogr 41 : $1242-1252$

Guo L, Wen LS, Tang D, Santschi PH (2000) Re-examination of cross-flow ultrafiltration for sampling aquatic colloids: evidence from molecular probes. Mar Chem 69:75-90

Guo L, Hunt BJ, Santschi PH (2001) Ultrafiltration behavior of major ions $\left(\mathrm{Na}, \mathrm{Ca}, \mathrm{Mg}, \mathrm{F}, \mathrm{Cl}, \mathrm{SO}_{4}\right)$ in natural waters. Water Res 35:1500-1508

Hedges JI (1992) Global biogeochemical cycles: progress and problems. Mar Chem 39:67-93

Hedges JI, Cowie GL, Richey JE, Quay PD, Benner R, Strom M, Forsberg BR (1994) Origins and processing of organic matter in the Amazon River as indicated by carbohydrates and amino acids. Limnol Oceanogr 39:743-761

Lee C, Wakeham SG (1992) Organic matter in the water column: future research challenges. Mar Chem 39:95-118

Libby PS, Wheeler PA (1997) Particulate and dissolved organic nitrogen in the central and eastern equatorial Pacific. Deep-Sea Res I 44:345-361

Mannino A, Harvey HR (2000) Terrigenous dissolved organic matter along an estuarine gradient and its flux to the coastal ocean. Org Geochem 31:1611-1625

McCarthy M, Pratum T, Hedges JI, Benner R (1997) Chemical composition of dissolved organic nitrogen in the ocean. Nature 390:150-154

Minagawa M, Wada E (1984) Stepwise enrichment of ${ }^{15} \mathrm{~N}$ along food chains: further evidence and the relation between $\delta^{15} \mathrm{~N}$ and animal age. Geochim Cosmochim Acta 48: $1135-1140$

Orlando SP Jr, Rozas LP, Ward GH, Klein CJ (1993) Salinity characteristics of Gulf of Mexico estuaries. NOAA, Office of Ocean Resources Conservation and Assessment, Silver Spring, MD

Rau GH, Sullivan CW, Gordon LI (1991) $\delta^{13} \mathrm{C}$ and $\delta^{15} \mathrm{~N}$ variations in the Weddell Sea particulate organic matter. Mar Chem 35:355-369

Rau GH, Teyssie JL, Rassoulzadegan F, Fowler SW (1990) ${ }^{13} \mathrm{C} /{ }^{12} \mathrm{C}$ and ${ }^{15} \mathrm{~N} /{ }^{14} \mathrm{~N}$ variations among size-fractionated marine particles: implications for their origin and trophic relationships. Mar Ecol Prog Ser 59:33-38

Editorial responsibility: Otto Kinne (Editor), Oldendorf/Luhe, Germany
Sachs JP, Repeta DJ, Goericke R (1999) Nitrogen and carbon isotopic ratios from marine phytoplankton. Geochim Cosmochim Acta 63:1430-1441

Sackett WM (1989) Stable carbon isotope studies on organic matter in the marine environment. In: Handbook of environmental isotope geochemistry, Vol 3. The marine environment. Elsevier, New York, p 139-169

Saino $\mathrm{T}(1992){ }^{15} \mathrm{~N}$ and ${ }^{13} \mathrm{C}$ natural abundance in suspended particulate organic matter from a Kuroshio warm-core ring. Deep-Sea Res I 39: S347-S362

Saino T, Hattori A (1987) Geographical variation in the water column distribution of suspended particulate organic nitrogen and its ${ }^{15} \mathrm{~N}$ natural abundance in the Pacific and its marginal seas. Deep-Sea Res I 34:807-827

Sanford LP, Suttles SE, Halka JP (2001) Reconsidering the physics of the Chesapeake Bay estuarine turbidity maximum. Estuaries 24:655-669

Santschi PH, Guo L, Baskaran M, Trumbore S, Southon J, Bianchi TS, Honeyman BD, Cifuentes L (1995) Isotopic evidence for contemporary origin of high-molecular weight organic matter in oceanic environments. Geochim Cosmochim Acta 59:625-631

Santschi PH, Guo L, Quigley MS, Baskaran M, Walsh I (1999) Boundary exchange and scavenging of radionuclides in continental margin waters of the Middle Atlantic Bight: implications for organic carbon fluxes. Cont Shelf Res 19: 609-636

Schell DM, Barnett BA, Vinette KA (1998) Carbon and nitrogen isotope ratios in zooplankton of the Bering, Chukchi and Beaufort sea. Mar Ecol Prog Ser 162:11-23

Sigleo AC, Macko SA (1985) Stable isotope and amino acid composition of estuarine dissolved colloidal material. In: Sigleo AC, Hattori A (eds) Marine and Estuarine Geochemistry. Lewis Publishers, Chelsea, MI, p 29-46

Struck U, Emis KC, Vob M, Krom MD, Rau GH (2001) Biological productivity during sapropel S5 formation in the Eastern Mediterranean Sea: evidence from stable isotopes of nitrogen and carbon. Geochim Cosmochim Acta 65: 3249-3266

Thornton SF, McManus JM (1994) Application of organic carbon and nitrogen stable isotope and $\mathrm{C} / \mathrm{N}$ ratios as source indicators of organic matter provenance in estuarine systems. Estuar Coast Shelf Sci 38:219-233

Wada E, Hattori A (1976) Natural abundance of $\delta^{15} \mathrm{~N}$ in particulate organic matter in the North Pacific Ocean. Geochim Cosmochim Acta 40:249-251

Williams PM (1968) Stable carbon isotopes in the dissolved organic carbon in the sea. Nature 219:152-153

Submitted: February 24, 2002; Accepted: November 14, 2002 Proofs received from author(s): April 5, 2003 